Jurnal AGRINIKA. September-2021. 5(2): 108-121

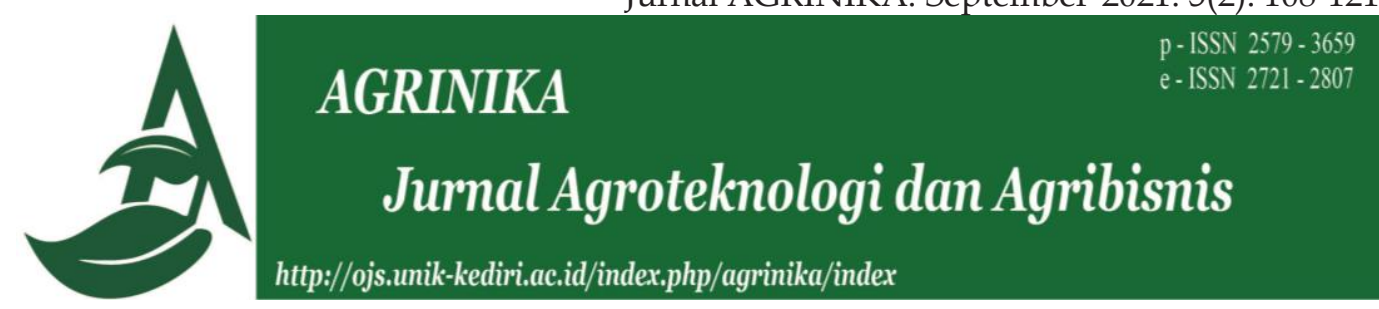

\title{
Komparasi Agribisnis Jamur Tiram (Pleurotus ostreatus) Media Tanam Limbah Sabut Kelapa dan Serbuk Gergaji
}

\author{
D. Yadi Heryadi ${ }^{1}$, Ristina Siti Sundari ${ }^{2}$, Rini Agustini ${ }^{3}$, Andang Hidayat $^{3}$ \\ ${ }^{1}$ Fakultas Pertanian, Universitas Siliwangi, Tasikmalaya, Indonesia \\ ${ }^{2}$ Fakultas Pertanian, Universitas Perjuangan, Tasikmalaya, Indonesia \\ ${ }^{3}$ Dinas Pertanian Kota Tasikmalaya, Jl. Leuwidahu No. 85, Tasikmalaya, Indonesia \\ *Korespondensi: ristina.sitisundari@yahoo.com \\ Diterima 07 Maret 2021/ Direvisi 10 September 2021/ Disetujui 15 September 2021
}

\begin{abstract}
ABSTRAK
Agribisnis jamur tiram (Pleurotus ostreatus) semakin diminati oleh karena permintaan terus meningkat. Kandungan gizinya lengkap dengan protein yang tinggi. Bahkan bagi vegetarian menjadi pengganti protein hewani. Media pertumbuhan jamur tiram biasanya menggunakan limbah serbuk gergaji. Media limbah serbuk sabut kelapa merupakan inovasi baru. Penelitian ini ingin mengetahui biaya-biaya hingga kelayakan usaha agribisnis jamur tiram menggunakan media limbah serbuk sabut kelapa dan yang biasa yaitu limbah serbuk gergaji Ternyata, Biaya total setahun menggunakan media limbah serbuk sabut kelapa lebih hemat Rp750.000 dibandingkan dengan media limbah serbuk gergaji. Biaya per kilogramnya sedikit lebih mahal Rp99.21 tetapi hasil panen lebih rendah dari limbah serbuk gergaji. Jamur tiram media limbah serbuk sabut kelapa memberikan keuntungan $133.29 \%$ dan media limbah serbuk gergaji $140.72 \%$. Jamur tiram media limbah serbuk gergaji memberikan keuntungan bersih/bulan rata-rata Rp2,739,694.50, sedangkan media limbah serbuk sabut kelapa rata-rata Rp2,511,769.50.Kedua media untuk jamur tiram sangat layak diusahakan dengan R/C ratio 2.33 dan 2.41. Pengusaha bisa mempertimbangkan media limbah serbuk sabut kelapa atau limbah serbuk gergaji tergantung ketersediaan di sekitar lokasi dengan informasi harga limbah sabut kelapa lebih murah daripada limbah serbuk gergaji.

Kata kunci : Jamur tiram; Kelayakan; Limbah; Sabut kelapa; Serbuk gergaji
\end{abstract}

\section{ABSTRACT}

The agribusiness of oyster mushrooms (Pleurotus ostreatus) is getting interested due to an increase in demand. It has almost complete nutrients, high protein content that can substitute animal protein for vegetarians. The growth medium for oyster mushrooms commonly uses sawdust. The cocopeat waste medium is an innovation. The research descriptively compares production cost, yield, revenue, income, and feasibility throughout both mediums. Findings that the total cost of sawdust medium was higher 750,000 IDR than cocopeat waste. In terms of income, sawdust medium earned $140.72 \%$, while cocopeat waste earned $133.29 \%$. The feasibility of sawdust waste was 2.41 while cocopeat waste was 2.33 as well. Otherwise, the cocopeat waste medium was higher 99.21IDR than sawdust waste in cost $/ \mathrm{kg}$ yield. Net income using cocopeat waste medium was $2,739,694.50$ IDR, and cocopeat waste was 2,511,769.50IDR on average. Both cocopeat waste and sawdust waste medium are very feasible to be an agribusiness. The consideration is that the availability surrounds the production site, and cocopeat waste is cheaper than sawdust waste. 
D. Yadi Heryadi, Komparasi Agribisnis Jamur ...

Keywords: Cocopeat; Feasibility; Oyster mushroom; Sawdust; Waste

\section{PENDAHULUAN}

Indonesia memiliki kekayaan alam berbagai jenis jamur yang terkemuka di dunia. Jamur-jamur tersebut ada yang tumbuh liar mapupun yang telah dibudidayakan atau dikembangkan secara komersial. Jamur adalah bahan pangan penuh gizi dan antioksidan yang memasyarakat. Jenis jamur yang mudah atau sering dijumpai di pasar adalah jamur champigno (Agaricus bitorquis), jamur shiitake (Lentinus edodes), jamur merang (Volvariella volvacea), dan jamur tiram (Pleurotus ostreatus). Jamur tiram lebih popular saat ini dan relatif lebih mudah dalam pembudidayaannya. Agribisnis jamur tiram dapat dilakukan menjadi bisnis utama sebagai mata pencaharian baik dalam skala rumah tangga, mikro, kecil, menengah maupun sedang. Juga sebagai hobi ataupun usaha sampingan. Popularitas jamur tiram sebagai bahan makanan yang lezat dan bergizi semakin meluas sehingga membuat aktifitas pasar perjamuran dan permintaan konsumen terhadap jamur tiram terus mengalami peningkatan di berbagai wilayah. Kebutuhan jamur tiram terus meningkat berbanding lurus dengan pertambahan populasi, pendapatan per kapita dan pola konsumsi masyarakat yang terus berubah menuju hidup lebih sehat. Kanada, Jerman, Amerika Serikat, Jepang, Hongkong, Belanda, Belgia, dan Italia merupakan negara pengkonsumsi jamur yang tinggi. Negara-negara di Eropa mengkonsumsi jamur melebihi $1,5 \mathrm{~kg}$ per kapita per tahun. Sehingga usahatani atau budidaya jamur sangat cocok untuk dilakukan dan dibudidayakan oleh masyarakat di Indonesia. Jamur memiliki potensi dan pangsa pasar yang sangat luas sehingga diharapkan mampu mendongkrak ketahanan pangan, nilai tambah yang menguntungkan dan melancarkan roda perekonomian masyarakat di Indonesia (Sundari et al., 2017, 2019, 2020).

Jamur termasuk kelompok divisi tumbuhan tingkat rendah yang hidupnya menempel pada inang lain untuk mendapatkan sumber nutrisinya karena tidak berforosintesis. Pada dasarnya jamur tumbuh liar menempel pada substansi-subnstansi yang mengalami proses pelapukan oleh adanya aktifitas mikroorganisme. Namun sekarang jamur sudah banyak dibudidayakan karena tinkat permintaan yang tinggi. Pada umumnya jamur tiram ditanam pada baglog atau media tanam. Kebanyakan petani jamur tiram di Indonesia menggunakan baglog dengan bahan baku limbah serbuk gergaji (sawdust) karena di sebagian daerah limbah serbuk gergaji (sawdust) mudah dijumpai.

Setiap usaha yang dijalankan terdapat beberapa kendala yang pasti dialami para pelaku usaha. Begitu juga pada usahatani jamur tiram ada beberapa kendala yang dialami oleh para petani jamur tiram. Kendala yang dialami para petani jamur yaitu kendala dalam bahan baku media tanam, kendala pada tingkat keberhasilan pembuatan baglog atau media tanam, kendala pada proses sterilisasi, lambatnya perkembangan miselium dan 
lain-lain (Sunandar et al., 2018). Tingkat kontaminasi media jamur tiram pada pembudidaya jamur tiram berkisar antara 10 sampai dengan 50 persen dan menyebabkan tingkat produktivitasnya menurun. Penyebab kegagalan pada usahatani jamur tiram diantaranya alat pasteurisasi media jamur tiram yang digunakan kurang efektif. Hal ini memberi kemungkinan besar media jamur tiram tersebut tidak optimal matangnya. Alat Pasteurisasi yang digunakan biasanya meliputi ruang pasteurisasi yang tidak rapat dengan pemanas dari tungku kayu yang sederhana.

Bahan baku yang umum digunakan para pembudidaya jamur untuk budidaya jamur tiram yaitu campuran serbuk kayu, dedak, dan kalsium karbonat atau kapur pertanian. Namun sebaiknya campuran bahan baku tersebut disesuaikan menurut lingkungan dan diharapkan dapat memanfaatkan limbah sekitar tempat budidaya sehingga dapat meringankan modal produksi dan menambah keuntungan dari pemanfaatan limbah. Di antara contoh pemanfaatan limbah yang dapat digunakan yaitu: limbah eceng gondok, limbah kertas, dan lain sebagainya. (1) Serbuk kayu: Pada umumnya pembudidaya menggunakan bahan baku media tanam jamur tiram adalah limbah penggergajian kayu atau lebih dikenal dengan serbuk kayu. Bahan tersebut mudah dijumpai dan mudah didapat dalam jumlah banyak di sebagian daerah. Serbuk kayu yang dapat digunakan meliputi hampir semua jenis kayu kecuali kayu yang mengandung kadar getah yang tinggi seperti pohon pinus, karet, dan lain-lain. (2) Limbah serbuk sabut kelapa: juga dapat dijadikan bahan baku media tanam jamur tiram, bahan tersebut mudah dijumpai dan harganya lebih murah dibandingkan dengan bahan baku lain karena limbah serbuk sabut kelapa sering dianggap sudah tidak memiliki kegunaan. Namun faktor yang paling menentukan pada tingkat keberhasilan penggunaan limbah serbuk sabut kelapa sebagai media tanam jamur tiram adalah lamanya waktu proses sterilisasi. (3) Dedak: Dedak adalah sisa dari hasil pengilingan padi yang umum digunakan dalam budidaya jamur tiram. Dedak berfungsi sebagai nutrisi tambahan dalam media tanam, semua jenis dedak padi dapat digunakan namun yang paling baik adalah dedak yang paling halus atau sering disebut bekatul. Dedak yang digunakan sebaiknya tidak lebih dari 15 hari dari hasil penggilingan padi dan tidak digunakan terlalu banyak karena dikhawatirkan memicu tumbuhnya jamur lain sejenis jamur oncom dan lain-lain. (4) Kalsium Karbonat $\left(\mathrm{CaCO}_{3}\right)$ : Untuk meningkatkan $\mathrm{pH}$ pada media tanam jamur para pembudidaya biasanya menggunakan kalsium karbonat atau sering disebut kapur.Penggunaan kalsium karbonat dapat diganti dengan kapur sirih, tepung cangkang kerang dan lain sebagainya.

Pemakaian kalsium karbonat sebaiknya disesuaikan dengan kondisi lingkungan tempat budidaya, seperti a. Kondisi lingkungan berkisar antara 15 derajat Celcius sampai dengan 20 derajat celcius menggunakan Kalsium Karbonat 3 persen. B. Kondisi lingkungan berkisar antara 21 derajat celcius sampai dengan $27^{\circ}$ Celcius menggunakan Kalsium Karbonat 2,5 persen. Kondisi lingkungan berkisar antara $28^{\circ}$ Celcius $-32^{\circ}$ Celcius menggunakan Kalsium Karbonat 2 persen. Penggunaan kalsium karbonat yang berlebihan dapat menghambat 
pertumbuhan miselium jamur, sedangkan kurangnya penggunaan kalsium karbonat dapat mempercepat pembusukan media tanam dan pertumbuhan belatung pada media tanam

Permasalahan yang dialami oleh petani jamur tiram adalah saat terjadi kenaikan harga limbah serbuk gergaji yang merupakan bahan baku paling utama untuk media tanam jamur tiram. Pemanfaatan limbah yang berasal dari serbuk sabut kelapa sebagai media tanam jamur tiram merupakan inovasi baru. Limbah serbuk sabut kelapa sebelumnya sebagai media tanam kentang. Namun penggunaannya hanya dipakai satu kali musim penanaman sehingga terdapat limbah serbuk sabut kelapa yang tidak termanfaatkan. Banyaknya limbah serbuk yang berasal dari sabut kelapa bekas media tanam kentang yang tersedia membuat kekhawatiran bagi sebagian petani disana, karena tidak menutup kemungkinan bahwa limbah tersebut akan menjadi tempat berkembangnya hama dan penyakit khususnya di bidang pertanian. Hal ini merupakan solusi alternatif masalah bagi para petani jamur tiram ketika terjadi kenaikan harga pada limbah serbuk gergaji (sawdust) yang merupakan bahan baku utama media tanam dalam usaha jamur tiram (Fatmawati, 2017; Hasriani et al., 2013a; Prasetyawan, 2009; Rambey et al., 2018)

Penelitian media limbah serbuk sabut kelapa dan limbah serbuk gergaji secara teknis cukup banyak dilakukan seperti untuk pertumbuhan padi (Antoro \& Nelvia, 2018; Yulia et al., 2018), bibit kakao (Hasriani et al., 2013b; Saputra et al., 2019), kelapa sawit (Andri et al., 2017), pembibitan meranti (Marjenah, 2016), kentang (Putra et al., 2019), hidroponik (Hasriani et al., 2013a; James et al., 2010), tanaman hias chrysanthemum (Singh et al., 2015), bahkan sebagai peredam dan bahan konstruksi bangunan di lahan basah (Danley-Thomson et al., 2016).

Memanfaatkan limbah serbuk sabut kelapa untuk media tumbuh jamur tiram ini masih tergolong ide baru sehingga diperlukan penelitian secara ekonomi karena belum banyak dilakukan. Terutama penelitian untuk mengetahui tingkat produksi, biaya oprasional, pendapatan, keuntungan dan kelayakan usaha agribisnis jamur tiram dengan media limbah serbuk sabut kelapa dibandingkan dengan limbah serbuk gergaji.

\section{BAHAN DAN METODE}

\section{Pengumpulan Data}

Penelitian ini mengambil data primer dan sekunder dan dianalisis secara deskriptif. Pengambilan data primer dan sekunder dilakukan untuk menggambarkan mengenai struktur biaya, pendapatan, keuntungan, dan kelayakan agribisnis jamur tiram yang biasa mennggunakan media limbah serbuk gergaji dengan inovasi baru menggunakan media limbah serbuk sabut kelapa. Data primer diperoleh dari hasil pemberian kuisioner kepada responden atau narasumber sebagai alat pengumpulan data yang pokok. Data kualitatif primer juga diperoleh dari observasi lapangan dan wawancara kepada masyarakat yang berlokasi dekat dengan lokasi penelitian. Data sekunder didapatkan dari buku, catatan, dokumen, dan referensi lainnya yang terkait dengan penelitian ini.

Penentuan responden pada penelitian ini menggunakan teknik purposive sampling, terhadap 
pembudidaya jamur tiram di Kecamatan Ibun Kabupaten Bandung. karena memiliki pengalaman dalam budidaya jamur tiram yang menggunakan media limbah serbuk gergaji yang juga mencoba menggunakan limbah serbuk sabut kelapa sebagai media tanam jamur tiram alternatif. Menurut (Wang, 2016) peneliti mengumpulkan data yang diperlukan dengan pertimbangan dan atau mengambil manfaat segala informasi di dalam kategori yang telah diperinci. Variabel-variabel yang dioperasikan dalam penelitian ini diantaranya: Pemanfaatan limbah yaitu kegiatan atau tindakan yang dilakukan manusia untuk menambah nilai jual dan kegunaan dari barang sisa yang dianggap sudah tidak bernilai dan tidak digunakan seperti limbah industri maupun rumah tangga Petani (produktif) adalah petani yang melakukan agribisnis jamur tiram dengan media limbah serbuk gergaji dan media limbah serbuk sabut kelapa sebagai responden penelitian.

\section{Definisi Opersionalisasi Variabel}

1. Pemanfaatan limbah yaitu kegiatan atau tindakan yang dilakukan manusia untuk menambah nilai jual dan kegunaan dari barang sisa yang dianggap sudah tidak bernilai dan tidak digunakan seperti limbah industri maupun rumah tangga.

2. Petani (produktif) adalah petani yang melakukan usahatani jamur tiram dengan media serbuk kayu dan media limbah cocopeat sebagai responden penelitian.

3. Biaya produksi berupa semua nilai pengorbanan yang diperlukan dalam suatu proses produksi untuk menghasilkan suatu barang/jasa atau produk yang siap dipasarkan. Yang terdiri dari biaya tetap (Fixed
Cost) dan biaya variabel (Variabel Cost)

4. Biaya tetap (Fixed Cost) adalah nilai biaya yang besar kecilnya tidak dipengaruhi oleh jumlah produksi yang dipakai dalam satu kali periode produksi. Penyusutan biaya peralatan dalam budidaya jamur tiram ini yaitu:

a) Penyusutan alat, dinilai dengan satuan rupiah (Rp). Menurut Suratiyah (2015) penyusutan alat bisa dihitung menggunakan metode garis lurus (straight-line method).

$$
\text { Penyusutan }=\frac{\text { Nilai Beli- }- \text { Nilai Sisa }}{\text { Umur Ekonomis } . .(1)}
$$

b) Pajak Bumi dan Bangunan (PBB) dihitung dengan satuan rupiah dalam satu kali proses produksi atau selama empat bulan (Rp/proses produksi).

5. Biaya variabel (Variabel Cost) yaitu biaya yang besar kecilnya dipengaruhi oleh jumlah produksi dan dihitung dalam satu kali periode produksi. Biaya variabel pada budidaya jamur tiram ini yaitu

1) Serbuk kayu, dihitung karung yang berkapasitas 70 kilogram (Rp/Karung)

2) Limbah cocopeat, dihitung dalam satuan rupiah per karung berkapasitas 70 kilogram (Rp/Karung)

3) Dedak, dihitung dengan satuan rupiah per kilogram $(\mathrm{Rp} / \mathrm{Kg})$

4) Kapur pertanian, dihitung dengan satuan rupiah per kilogram $(\mathrm{Rp} / \mathrm{Kg})$

5) Bibit jamur, dihitung dengan satuan rupiah per botol (Rp/Botol)

6) Plastik PP, dihitung dengan satuan rupiah per kilogram $(\mathrm{Rp} / \mathrm{Kg})$

7) Alkohol, dihitung dengan satuan rupiah per liter (Rp/Liter) 
8) Spirtus, dihitung dalam satuan rupiah per liter (Rp/Liter)

9) Koran bekas, dihitung dalam satuan rupiah per kilogram $(\mathrm{Rp} / \mathrm{Kg})$

10) Isi ulang Gas LPG, dihitung dalam satuan rupiah per tabung (Rp/Tabung)

11) Tenaga kerja, dihitung dalam satuan rupiah per satu kali proses produksi atau selama empat bulan.

6. Hasil produksi: hasil yang dikeluarkan dari suatu proses produksi yaitu produk olahan berbahan baku sorgum yang dinilai dengan satuan kilogram $(\mathrm{kg})$.

7. Harga jual untuk setiap produk hasil olahan sorgum yang dinilai dengan satuan rupiah (Rp).

8. Pendapatan adalah semua uang atau alat pembayaran lain yang diterima dari kegiatan usaha pada satu periode waktu.

9. Penerimaan adalah pendapatan yang telah dikurangi dengan beban usaha dan pajak pada periode waktu tertentu.

10. $\mathrm{R} / \mathrm{C}$ ratio: jumlah rasio yang digunakan untuk mengetahui keuntungan relatif yang akan didapatkan dalam suatu kegiatan usaha. Pengambilan keputusan pada $\mathrm{R} / \mathrm{C}$ ini, yaitu :

$\mathrm{R} / \mathrm{C}>1$, berarti usahatani layak dijalankan

$\mathrm{R} / \mathrm{C}=1$, berarti usahatani impas

$\mathrm{R} / \mathrm{C}<1$, berarti usahatani tidak layak dijalankan

11. Penelitian komparasi adalah penelitian yang bertujuan membandingkan ditinjau dari data yang terkumpul setelah peristiwa yang dipermasalahkan terjadi.
Analisis Data

Biaya produksi dikategorikan semua pengorbanan yang diperlukan untuk menghasilkan produk dalam suatu proses produksi yang siap dipasarkan. Biaya tetap (Fixed Cost) ukurannya tidak ditentukan oleh jumlah produk dan digunakan dalam satu periode produksi. Penyusutan biaya peralatan dalam budidaya jamur tiram ini yaitu : a) Penyusutan alat, dinilai dalam Rupiah (Rp). Menurut (Shinta, 2011; Suratiyah, 2015) nilai penyusutan alat dihitung metode garis lurus (straight-line method). Formula yang digunakan adalah:

$$
\text { Penyusutan }=\frac{\text { Nilai Beli-Nilai Sisa }}{\text { Umur Ekonomis }} \ldots . . .(2)
$$

PBB dihitung dalam rupiah dalam satu periode produksi (Rp/periode produksi). Sedangkan Biaya Variabel (Variabel Cost) biaya-biaya yang ukurannya dipengaruhi oleh jumlah produksi dan dipakai dalam satu kali periode produksi.

Hasil produksi yaitu hasil yang dikeluarkan dari suatu proses produksi dalam satuan kilogram (kg). Harga jual untuk setiap produk hasil panen dinilai dengan satuan rupiah (Rp). Pendapatan adalah semua uang atau alat pembayaran lain yang diterima dari kegiatan usaha pada satu periode waktu. Penerimaan adalah pendapatan yang telah dikurangi dengan beban usaha dan pajak pada periode waktu tertentu. R/C Ratio adalah jumlah rasio perbandingan untuk melihat keuntungan relatif yang akan didapatkan dalam suatu kegiatan usaha. Pengambilan keputusan pada $R / C$ ini, yaitu : R/C $>1$, maka agribisnis jamur tiram layak dijalankan; $\mathrm{R} / \mathrm{C}=1$, maka agribisnis jamur tiram impas; R/C $<1$, maka agribisnis jamur tiram tidak layak dijalankan. 
Untuk mengetahui besarnya total biaya produksi dari agribisnis jamur tiram bermedia limbah serbuk gergaji dan jamur tiram bermedia limbah serbuk sabut kelapa, maka digunakan rumus sebagai berikut :

$$
\mathrm{TC}=\mathrm{TFC}+\mathrm{TVC}
$$

Dimana:

$\mathrm{TC}=$ Biaya total agribisnis jamur tiram, $\mathrm{TFC}=$ Biaya Tetap agribisnis jamur tiram TVC= Biaya Tidak Tetap agribisnis jamur tiram.

Untuk mengetahui besarnya total penerimaan dari agribisnis jamur tiram bermedia limbah serbuk gergaji dan jamur tiram bermedia limbah serbuk sabut kelapa rumusnya sebagai berikut :

$$
\mathrm{TR}=\mathrm{Y} \cdot \mathrm{P}_{\mathrm{y}}
$$

Dimana:

TR: Penerimaan Total agribisnis jamur tiram $Y$ : Jumlah Produksi agribisnis jamur tiram $P_{y}$ : Harga Produksi agribisnis jamur tiram.

Sedangkan besarnya pendapatan dari agribisnis jamur tiram bermedia limbah serbuk gergaji dan jamur tiram bermedia limbah serbuk sabut kelapa, rumusnya sebagai berikut :

$$
\mathrm{I}=\mathrm{TR}-\mathrm{TC}
$$

Dimana:

I : Pendapatan agribisnis jamur tiram

TR : Penerimaan Total agribisnis jamur tiram

TC : Biaya Total agribisnis jamur tiram

Untuk mengetahui tingkat kelayakan atau $\mathrm{R} / \mathrm{C}$ ratio dari agribisnis jamur tiram bermedia limbah serbuk gergaji dan jamur tiram bermedia limbah serbuk sabut kelapa, maka rumusnya sebagai berikut :

$$
\mathrm{R} / \mathrm{C}=\frac{\mathrm{TR}}{\mathrm{TC}}
$$

Dimana:

$\mathrm{R} / \mathrm{C}$ : Besarnya pendapatan yang diperoleh dari setiap rupiah yang diperoleh dari agribisnis jamur tiram
TR : Penerimaan Total agribisnis jamur tiram

TC : Biaya total agribisnis jamur tiram

Analisis $\mathrm{R} / \mathrm{C}$ ratio digunakan untuk mengatahui kelayakan usaha agribisnis jamur tiram yang dijalankan. Pengambilan keputusan pada analisis $\mathrm{R} / \mathrm{C}$ ini, yaitu jika: R/C > 1, maka agribisnis jamur tiram layak untuk dilanjutkan; $\mathrm{R} / \mathrm{C}=1$, berarti agribisnis jamur tiram impas (agribisnis yang diusahakan tidak untung dan tidak rugi); dan $\mathrm{R} / \mathrm{C}<1$, maka agribisnis jamur tiram tidak layak untuk dilanjutkan.

\section{HASIL DAN PEMBAHASAN}

Hasil penelitian ini bersifat deskriptif dengan membandingkan komponen-komponen biaya dan hasil yang menjadi pengeluaran ataupun pemasukan dari kegiatan agribisnis jamur tiram. Hal ini sejalan dengan pendapat (Nazir, 2013) penelitian komparasi yaitu jenis penelitian untuk membandingkan suatu variabel tertentu yang berpengaruh pada objek yang diteliti. Kegiatan produksi agribisnis jamur tiram pada 4 unit banguan dengan ukuran yang sama yaitu $4 \mathrm{~m} \times 8$ m. Proses produksi dilakukan 3 kali dalam setahun. Perhitungan tingkat bunga modal disesuaikan dengan KUR yang berlaku pada Bank BRI yaitu sebesar 7 persen setahun. Dalam satu kali prosed produksi diketahui tingkat bunga sebesar 1.75 persen. Hasil panen jamur tiram dipasarkan dengan dua rantai pasar yaitu dari produsen yang langsung diterima konsumen dan dari produsen yang bertahap melalui distributor baru ke konsumen. Sistem transaksi yang dijual secara langsung kepada konsumen maupun melalui distributor dilakukan pembayaran secara tunai atau pembayaran 
D. Yadi Heryadi, Komparasi Agribisnis Jamur ...

langsung, setiap penjualan jamur tiram responden selalu mencatat sebagai transaksi rutin. Hal ini merupakan salah satu manajemen pemasaran yang cukup efektif (Kotler, 2013, 2011, 2012b, 2012a; Kotler \& Keller, 2016).

Tabel 1. Biaya total usaha jamur tiram dengan media limbah serbuk gergaji dan limbah serbuk sabut kelapa (Rp)

\begin{tabular}{rrrrr}
\hline No. & Uraian & $\begin{array}{c}\text { Limbah Serbuk } \\
\text { Gergaji }\end{array}$ & $\begin{array}{c}\text { Limbah Serbuk } \\
\text { Sabut Kelapa }\end{array}$ & \multicolumn{2}{c}{ Selisih } \\
\hline 1 & Biaya Tetap & 208.102 & 208.102 & 0 \\
2 & Biaya Variabel & 7.569 .000 & 7.484 .000 & 85.000 \\
\hline & Biaya Total & 7.777 .102 & 7.692 .102 & 85.000 \\
\hline
\end{tabular}

Biaya Total Agribisnis Jamur Tiram terdiri dari biaya tetap (Fixed Cost) dan biaya tidak tetap (Variable Cost). Biaya tetap yang telah dikeluarkan untuk agribisnis Jamur Tiram dengan media serbulk gergaji sebesar Rp208.102. yang terdiri dari penyusutan alat Rp164.700 dan buang modal tetap Rp3.502. Biaya variable yang dikeluarkan untuk agribisnis Jamur Tiram sebesar Rp7.569.000 yang terdiri dari limbah serbuk gergaji (sawdust), bekatul (dedak), dolomit, bibit jamur, plastic PP, alcohol, spirtus, koran bekas, LPG $3 \mathrm{~kg}$, tenaga kerja. Keseluruhan biaya variable dan biaya non variable disebut biaya total, yang dibutuhkan menjadi Rp7.777.102. Dengan biaya total sebesar itu dapat memanen jamur tiram sebanyak $1.874,67 \mathrm{~kg}$ dalam satu periode produksi. Hasil panen dijual ke pengepul seharga Rp7.500 tiap kilogramnya. Dengan asumsi langsung terjual habis, hasil penjualan diterima sebesar Rp14.060.025 dan keuntungan yang diperoleh sebesar Rp6.282.923 yaitu sebesar 181 persen. Agribisnis jamur tiram dengan media limbah serbuk gergaji dikalkulasi membutuhkan biaya Rp4.148,52 per kilogram hasil panen dengan tingkat kelayakan usaha sebesar 2,41. Hal ini berarti setiap 1 rupiah yang dikeluarkan akan memperoleh keuntungan sebesar 2, 41 rupiah.

Biaya Total Agribisnis Jamur Tiram dengan media limbah serbuk gergaji terdiri dari biaya tetap dan biaya tidak tetap. Biaya tetap yang dikeluarkan untuk agribisnis Jamur Tiram dengan media limbah cocopeat sebesar Rp208.102 yang terdiri dari penyusutan alat sebesar Rp164.700 dan buang modal tetap sebesar Rp3.502. Biaya tetap yang dikeluarkan sama dengan biaya tetap dengan media limbah serbuk gergaji. Biaya variable yang dikeluarkan untuk agribisnis Jamur Tiram sebesar Rp7.484.000 yang terdiri dari limbah serbuk gergaji (sawdust), bekatul (dedak), dolomit, bibit jamur, plastic PP, alcohol, spirtus, koran bekas, LPG $3 \mathrm{~kg}$, tenaga kerja. Keseluruhan biaya variable dan biaya non variable disebut biaya total, yang dibutuhkan menjadi Rp7.692.102. Dengan biaya total sebesar itu dapat memanen jamur tiram sebanyak $1.751,50 \mathrm{~kg}$ dalam satu periode produksi. Hasil panen dijual ke pengepul seharga Rp7.500 tiap kilogramnya. Dengan asumsi langsung terjual habis, hasil penjualan diterima sebesar Rp13,136,250.00 dan keuntungan yang diperoleh sebesar Rp5,609,148.00 yaitu sebesar 175 persen. Agribisnis jamur tiram dengan media limbah serbuk gergaji dikalkulasi 
membutuhkan biaya Rp4,297.52 per kilogram hasil panen dengan tingkat kelayakan usaha sebesar 2,33. Hal ini dapat diartikan bahwa setiap mengeluarkan biaya 1 rupiah akan menghasilkan keuntungan sebasar 2, 33 rupiah.

Tabel 2. Keuntungan, biaya per $\mathrm{Kg}$ hasil, persen keuntungan dan kelayakan usaha pada luas bangunan $4 \mathrm{~m} \times 8 \mathrm{~m}$ dengan media serbuk gergaji (sawdust)

\begin{tabular}{llrrr}
\hline No & \multicolumn{1}{c}{ Uraian } & $\begin{array}{c}\text { Media Limbah } \\
\text { serbuk gergaji }\end{array}$ & $\begin{array}{c}\text { Media } \\
\text { Limbah } \\
\text { Sabut Kelapa }\end{array}$ & \multicolumn{1}{c}{ Selisih } \\
\hline 1 & Biaya Total (Rp) & $7,777,102.00$ & $7,527,102.00$ & $250,000.00$ \\
2 & Hasil Produksi (kg) & $1,874.67$ & $1,751.50$ & 123.17 \\
3 & Harga per kg & $7,500.00$ & $7,500.00$ & sama \\
4 & Penerimaan (Rp) & $14,060,025.00$ & $13,136,250.00$ & $923,775.00$ \\
5 & Keuntungan/pendapatan & $6,282,923.00$ & $5,609,148.00$ & $673,775.00$ \\
6 & (Rp) & $4,148.52$ & $4,297.52$ & $(149.00)$ \\
7 & Piaya per kg hasil (Rp) & 181 & 175 & 6 \\
8 & Kersen keuntungan (\%) & 2.41 & 2.33 & 0.07 \\
\hline & & & & \\
\hline
\end{tabular}

Analisis deskriptif (Tabel 2) menunjukkan bahwa selama satu kali proses produksi dengan media limbah serbuk gergaji menghasilkan $1.84,67 \mathrm{~kg}$ jamur tiram sedangkan media limbah serbuk sabut kelapa menghasilkan $1.751,50 \mathrm{~kg}$, selisih 123,17 kg. Produsen menjual hasil panen jamur tiram kepada pengepul Rp7.500 baik yang menggunalam media limbah serbuk gergaji maupun limbah serbuk sabut kelapa. Pengepul datang langsung ke lokasi produksi. Produsen menjual hasil panen ke konsumen langsung lebih tinggi daripada ke pengepul yaitu Rp10.000 - 14.000 per kg. Hal ini akan berdampak kepada keuntungan dan tingkat kelayakan usaha.

Hal ini dikarenakan konsumen langsung membeli jamur tiram dalam jumlah sedikit hanya untuk memenuhi kebutuhan makan keluarganya. Itupun konsumen masih diuntungkan karena membeli langsung ke produsen dengan harga beli yang lebih murah jika dibandingkan dengan membeli ke pasar tradisional maupun pasar swalayan. Di sini terbentuk market share dan consumer share yang sama-sama diuntungkan (Wilbur \& Farris, 2014) melalui saluran distribusi (Tian \& Jiang, 2018).

Limbah serbuk gergaji memliki kelebihan dan kekurangan sebagai media tanam. Kelebihannya adalah mudah menyimpan dan menyerap air, berpori, teksturnya ringan, ramah lingkungan. Kekurangannya adalah sedikit unsur hara, mudah diserang jamur, hanya cocok untuk perakaran lembab, banyak mengandung tanin.

Serbuk kayu sebagai media tanam biasanya digunakan jika menanam menggunakan pot atau polybag. Serbuk ini dipilih karena teksturnya yang ringan, sehingga pertumbuhan dan perkembangan akar akan lebih cepat. Memiliki pori-pori dengan kadar porositas yang tinggi namun masih bisa diatur kepadatanya. Untuk mendapatkan tingkat porositas yang diinginkan bisa dilakukan dengan mengatur rasio air yang akan diberikan. Jadi berfungsi sebagai pelembab tanah. Namun 
demikian terdapat beberapa kekurangannya, yaitu sangat mudah tumbuh jamur aflatoxin. Jangan membiarkan tanaman terlalu lama dalam keadaan lembab maka dengan kondisi media ini perakranan akan mati. Intensitas cahaya yang cukup sangat diperlukan.

Biaya produksi agribisnis jamur tiram dengan media limbah serbuk gergaji lebih tinggi Rp250,000 selisihnya dari media limbah serbuk sabut kelapa), Masing-masing sebesar Rp7,777,102 rupiah dan 7,527,102 rupiah. Besarnya jumlah biaya produksi disebabkan karena kualitas ataupun kuantitas bahan dan alat yang digunakan saat proses produksi (Felicia \& Gultom, 2018; Oentoe, 2013; Rasul, Agung Abdul Wijiharjono, Nuryadi Setyowati, 2013). Total penerimaan selama satu kali proses produksi agribisnis jamur tiram dengan media limbah serbuk gergaji adalah sebesar Rp14,060,025.00 dan jamur tiram dengan media limbah serbuk sabut kelapa adalah sebesar Rp13,136,250.00, terdapat selisih penerimaan lebih kecil Rp923,775.00 jika menggunakan media limbah serbuk sabut kelapa.

Pendapatan merupakan selisih antara total penerimaan dengan total biaya produksi maka pendapatan atau keuntungan bersih agribisnis jamur tiram dengan media limbah serbuk gergaji adalah sebesar Rp6,282,923.00 dan jamur tiram dengan media limbah serbuk sabut kelapa adalah sebesar Rp5,609,148.00. Ada selisih keuntungan sebesar Rp673,775.00. Jamur tiram dengan media limbah serbuk gergaji memberikan keuntungan bersih tiap bulan rata-rata $2,739,694.50$ rupiah, sedangkan media limbah serbuk sabut kelapa rata-rata $2,511,769.50$ rupiah per bulan.
Limbah serbuk sabut kelapa juga memiliki kelebihan dan kekurangan yang mirip dengan limbah serbuk gergaji. Kelebihannya antara lain mudah menyimpan dan meyerap air, memiliki tekstur yang menyerap air tanah, ramah lingkungan. Sedangkan kekurangannya adalah sedikit unsur hara, kurang sesuai untuk akar tanaman yang tidak menyukai kondisi basah, banyak mengandung tanin.

Jika di lokasi banyak terdapat limbah serbuk sabut kelapa (cocopeat) yang harganya lebih murah daripada limbah serbuk gergaji (sawdust) maka biaya media akan lebih murah. Jika di lokasi tidak terdapat media limbah serbuk gergaji (sawdust), akan ada tambahan biaya transportasi untuk pembelian limbah serbuk gergaji (sawdust), sehingga biaya produksi akan lebih mahal. Dalam penelitian ini kedua media tersebut ada di sekitar lokasi produksi. Biaya per $\mathrm{kg}$ hasil jika menggunakan limbah serbuk gergaji (sawdust) membutuhkan Rp4,148.52 dan jika menggunakan limbah serbuk sabut kelapa (cocopeat) membutuhkan Rp4,297.52, lebih tinggi sebesar Rp149.

Hasil perhitungan tingkat kelayakan usaha untuk agribisnis jamur tiram dengan media limbah serbuk gergaji (sawdust) sebesar 2.41 lebih besar senilai 0.07 selisihnya dari media limbah serbuk sabut kelapa (cocopeat) sebesar 2.33. Sehingga dapat diketahui bahwa keduanya memberi keuntungan yang besar sehingga layak untuk dilanjutkan. Hal ini dapat diartikan setiap biaya satu rupiah yang dikeluarkan pada agribisnis jamur tiram dengan media limbah serbuk gergaji (sawdust) mendapat keuntungan sebesar 1.41 rupiah dan untuk jamur tiram dengan media limbah serbuk sabut kelapa (cocopeat) mendapat keuntungan 
sebesar 1.33 rupiah. Peluang usaha dan potensi keuntungan jamur tiram masih terbuka lebar. Prospek pasar jamur tiram juga sangat luas (Zulfarina et al., 2019) mencakup berbagai kalangan masyarakat.

Pengepul datang langsung ke lokasi produksi. Produsen menjual hasil panen ke konsumen langsung lebih tinggi daripada ke pengepul yaitu Rp10.000 - 14.000 per kg. Hal ini akan berdampak kepada keuntungan dan tingkat kelayakan usaha.

\section{KESIMPULAN}

Kesimpulan

Biaya total selama setahun menggunakan media limbah serbuk sabut kelapa lebih hemat Rp750.000 dibandingkan dengan media limbah serbuk gergaji. Biaya media limbah serbuk sabut kelapa per kilogramnya sedikit lebih mahal 99.21 rupiah tetapi hasil panen lebih rendah dari limbah serbuk gergaji yaitu 123.7 rupiah. Jamur tiram dengan media limbah serbuk sabut kelapa memberikan keuntungan $133.29 \%$ dan media sawdust $140.72 \%$ rupiah. Jamur tiram dengan media serbuk gergaji memberikan keuntungan bersih tiap bulan rata-rata 2,739,694.50 rupiah, sedangkan media limbah serbuk sabut kelapat rata-rata $2,511,769.50$ rupiah per bulan. Kedua media untuk jamur tiram sangat layak diusahakan dengan $\mathrm{R} / \mathrm{C}$ ratio media limbah serbuk sabut kelapa 2,33 dan media sawdust 2,41 . Pengusaha agribisnis jamur tiram bisa mempertimbangkan keputusan menggunakan media limbah seruk sabut kelapa atau limbah serbuk gergajit tergantung ketersediaan di sekitar lokasi dengan informasi harga limbah serbuk sabut kelapa lebih murah daripada limbah serbuk gergaji.
Saran

Penggunaan media limbah serbuk sabut kelapa bagus digunakan sebagai media tumbun jamur tiram sebagai media bahan pengganti serbuk gergaji jika ketersediaanya berkurang. Bisa digunakan sebagai media utama karena harganya yang lebih murah dari pada serbuk gergaji. Perlu dilakukan penelitian lebih lanjut mengenai tingakt efisiensinya, baik efisiensi teknis maupun ekonomis.

\section{UCAPAN TERIMAKASIH}

Terimakasih yang tak terhingga kami ucapkan kepada narasumber pengusaha agribisnis Jamur Tiram di Kecamatan Ibun Kabupaten Bandung.

\section{DAFTAR PUSTAKA}

Andri, S., Nelvia, N., \& Saputra, S. I. (2017). Pemberian Kompos TKKS dan Cocopeat pada Tanah Subsoil Ultisol terhadap Pertumbuhan Bibit Kelapa Sawit (Elaeis guineensis Jacq.) di Pre Nursery. JURNAL AGROTEKNOLOGI. https://doi.org/10.24014/ja.v7i1.224 2

Antoro, P., \& Nelvia, N. (2018). Pertumbuhan Padi Gogo di Medium Ultisol dengan Pemberian Campuran Fosfat Alam dan Cocopeat pada Dua Kondisi Kadar Air. Jurnal Solum. https://doi.org/10.25077/jsolum.15.2 .60-65.2018

Danley-Thomson, A. A., Robbins, D. M., \& Gunsch, C. K. (2016). Cocopeat for wastewater treatment in the developing world. II: Field evaluation of constructed wetlands packed with cocopeat for wastewater treatment in Can Tho, 
Vietnam. Journal of Environmental Engineering (United States). https://doi.org/10.1061/(ASCE)EE.1 943-7870.0000996

Fatmawati. (2017). Berbagai Komposisi Media Tanam Serbuk Gergaji Kayu dan Serbuk Sabut Kelapa ( Cocopeat ). In Skripsi.

Felicia, \& Gultom, R. (2018). Pengaruh Biaya Produksi, Biaya Kualitas Dan Biaya Promosi Terhadap Laba Bersih Pada Perusahaan Manufaktur Yang Terdaftar Di Bursa Efek Indonesia Periode 2013 - 2015. Jurnal IImu Manajemen. https://doi.org/10.1016/j.amepre.20 07.12.024.Web-Based

Hasriani, Kalsim, D. K., \& Sukendro, A. (2013a). Kajian Serbuk Sabut Kelapa (Cocopeat) sebagai Media Tanam. IPB Press.

Hasriani, Kalsim, D. K., \& Sukendro, A. (2013b). Kajian Serbuk Sabut Kelapa (Cocopeat) sebagai Media Tanam. In IPB Press.

James, T. K., Rahman, A., \& Dickson, M. (2010). Survival of weed seeds in cocopeat bricks for hydroponics. New Zealand Plant Protection. https://doi.org/10.30843/nzpp.2010. 63.6582

Kotler. (2013). Manajemen Pemasaran Jilid 2. In Penerbit Erlangga.

Kotler, P. (2011). Reinventing Marketing to Manage. Journal of Marketing. https://doi.org/10.159/jmkg.75.4.132

Kotler, P. (2012a). Kotler On Marketing. In Kotler On Marketing.

Kotler, P. (2012b). Marketing
management/Philip Kotler, Kevin Lane Keller. Pearson Education International.

Kotler, P., \& Keller, K. L. (2016). A Framework for Marketing Management. In Marketing Management.

Marjenah, M. (2016). The effect of biochar, cocopeat and saw dust compost on the growth of two dipterocarps seedlings. Nusantara Bioscience.

https://doi.org/10.13057/nusbiosci/n 080108

Nazir, M. (2013). Resreach Method (R. Sikumbang (ed.); 8th ed.). Ghalia Indonesia.

Oentoe, C. (2013). Analisis Perhitungan biaya produksi menggunakan metode variable costing. EMBA.

Prasetyawan, D. (2009). Sifat Fisis dan Mekanis Papan Komposit Dari Serbuk Sabut Kelapa (Cocopeat) Dengan Plastic Polyethylene. Skripsi.

Putra, F. P., Saparso, S., Rohadi, S., \& Ismoyojati, R. (2019). Respon Tanaman Kentang (Solanum tuberosum L.) pada Berbagai Ketebalan Media Cocopeat Waktu Pemberian Nutrisi Sundstrom. Jurnal IImiah Pertanian. https://doi.org/10.31849/jip.v15i2.19 50

Rambey, R., Matondang, G. P. N., \& Siregar, E. B. M. (2018). Growth and productivity of mushroom oyster (Pleurotus ostreatus) on mixed planting media of cocopeat with sawdust. IOP Conference Series: Earth and Environmental 
D. Yadi Heryadi, Komparasi Agribisnis Jamur ...

Science.

https://doi.org/10.1088/1755-

1315/209/1/012035

Rasul, Agung Abdul Wijiharjono, Nuryadi Setyowati, T. (2013). Biaya Produksi. Ekonomi Mikro.

Saputra, E., Subiantoro, R., \& Gusta, A. R. (2019). Pengaruh Kombinasi Media Lapisan Tanah dan Takaran Cocopeat pada Pertumbuhan Bibit Kakao (Theobroma cacao L.). Jurnal Agro Industri Perkebunan. https://doi.org/10.25181/jaip.v7i1.10 51

Shinta, A. (2011). IImu Usahatani. In Jakarta.

Singh, S., Dubey, R. K., \& Kukal, S. S. (2015). Performance of cocopeat amended media mixtures on growth and flowering of chrysanthemum. Journal of Applied Horticulture. https://doi.org/10.37855/jah.2015.v1 7i03.44

Sunandar, A., Sumarsono, R. B., Witjoro, A., \& Husna, A. (2018). Budidaya Jamur Tiram: Upaya Menyerap Tenaga Kerja dan Meningkatkan Kesejahteraan Pemuda Desa. Abdimas Pedagogi, 1(2), 114-121.

Sundari, R. S., Kusmayadi, A., Hidayati, R., \& Arshad, A. (2020). Meningkatkan Kualitas dan Preferensi Konsumen Telur Itik dengan cara Menurunkan Level Bau Amis Telur Asin yang Diperkaya Antioksidan Daun Jintan (Plectranthus amboinicus L SPRENG). Mimbar Aagribisnis: Jurnal Pemikiran Masyarakat IImiah Berwawasan Agribisnis, 6(2), 853860. https://doi.org/http://dx.doi.org/10.2 5157/ma.v6i2.3590

Sundari, R. S., Kusmayadi, A., \& Umbara, D. S. (2017). Komparasi nilai Tambah Agroindustri Abon Ikan Lele dan Ikan Patin di Tasikmalaya. Jurnal Pertanian Agros, 19(1), 45-54.

Sundari, R. S., Umbara, D. S., Fitriadi, B. W., \& Sulaeman, M. (2019). Consumer Preference on Catfishes ( Patin and Lele) Sweetmeat Product. Journal of Physic: Conf.Series, 1179. https://doi.org/10.1088/17426596/1179/1/012166

Suratiyah, K. (2015). Ilmu Usahatani. In S. R. Anisa (Ed.), Jakarta (revisi). Penebar Swadaya.

Tian, L., \& Jiang, B. (2018). Effects of Consumer-to-Consumer Product Sharing on Distribution Channel. Production and Operations Management.

https://doi.org/10.1111/poms.12794

Wang, H.-R. (2016). How to write a good Data in Brief article. Elsevier.

Wilbur, K. C., \& Farris, P. W. (2014). Distribution and Market Share. Journal of Retailing. https://doi.org/10.1016/j.jretai.2013. 08.003

Yulia, R., Nelvia, N., \& Ariani, E. (2018). Pengaruh Campuran Cocopeat dan Rock Phosphate terhadap Pertumbuhan dan Hasil tiga Varietas Padi Gogo (Oryza sativa L.) pada Medium Ultisol. Jurnal Solum. https://doi.org/10.25077/jsolum.15.1 .17-25.2018 
D. Yadi Heryadi, Komparasi Agribisnis Jamur ...

Zulfarina, Z., Suryawati, E., Yustina, Y.,

Putra, R. A., \& Taufik, H. (2019).

Budidaya Jamur Tiram dan

Olahannya untuk Kemandirian

Masyarakat Desa. Jurnal

Pengabdian Kepada Masyarakat

(Indonesian Journal of Community

Engagement), 5(3), 358.

https://doi.org/10.22146/jpkm.44054 